\title{
DEVELOPMENT OF VARIATIONS IN GREETINGS BEFORE AND AFTER LEARNING THE MORAL CHARACTER OF STUDENTS IN ELEMENTARY SCHOOLS
}

\author{
${ }^{1}$ Muhammad lqbal Arrosyad, ${ }^{2}$ Fandi Nugroho \\ ${ }^{12}$ STKIP Muhammadiyah Bangka Belitung, INDONESIA
}

Received $18^{\text {th }}$ August $2020 \cdot$ Revised 24 $4^{\text {th }}$ September $2020 \cdot$ Accepted $28^{\text {th }}$ September 2020

\begin{abstract}
The development of various greetings before and after learning is made to provide additional references and treatment from teachers to students in interesting learning. The purpose of this study was to describe the development of a variety of greetings before and after learning in Public Elementary School 5 Mendo Barat. The research method used is the Research and Development method with the Thiagarajan Four-D development model which consists of four stages of research, namely (1) defining, including initial analysis, student analysis, concept analysis, and formulation of learning objectives; (2) planning (design) media selection, format selection, and preparation of various greeting media before and after learning; (3) development, including expert validation and testing; and (4) disseminate, including reproduction, socialization, and reflection. The results of this research. The definition stage 1) there is no media variation of greetings before and after learning; 2 ) lack of student moral character, and 3) teachers do not have information or references related to variations in greetings before and after learning. Researchers began to design a variety of greeting media with preface, table of contents, contents, author's biography, and back cover, on A4 paper size and $12 \mathrm{pt}$ Garamond font. The variety of media greetings before and after learning resulted from the teacher's response to $93.33 \%$ of the process. It can be seen from the greeting activities before and after learning the moral character of students. The moral character is not indifferent when invited to discuss, resulting in $60 \%$ of the 20 students, the character of piety including a sense of responsibility and good cooperation of the students as much as $60 \%$, the character of polite and respectful with students greeting by shaking hands every time they go to school, speaking politely $70 \%$ of teachers and friends, the character of manners in the form of like to help friends if asked for help as much as $70 \%$.
\end{abstract}

Keywords: development of various greetings, moral character

\section{INTRODUCTION}

The times are always changing and developing according to changing conditions [1]. The development of the era which is meant to be a development that is abstract and fictional in nature is visible and which cannot be seen. What can be seen is the development of technology and the development of merchandise. Meanwhile, the development that cannot be seen is the development of the character or nature of humans. [2] the development of the times continues and continues to give birth to various kinds of technology and new things.

Character development is always different, it is due to different human conditions [3], and depending on the factors that affect a person. The factor of someone who can influence is someone who often interacts and is in the same environment, and what makes the difference exist with the same situation and environment is the character of the person himself. The attitude or perception carried out by someone is different.

Based on a situation which is one of the factors in changing a person's character, then that situation is closely related to the environment. [4] the environment will be someone's object in communicating and communicative people can usually easily be accepted in their (c) 2020 by the authors; licensee PGSD UMP. This article is an open access article distributed under the terms and conditions of the Creative Commons Attribution License (http://creativecommons.org/licenses/by/4.0/). 
environment. The environment in question is the environment at school or outside of school, or the environment inside the classroom or outside the classroom such as at home or outside the home.

The school environment is a student learning environment that is very complex and very engaging. This is because the school environment is an environment that is a place of learning every day except holidays, [5] The school environment is a factor that can influence changes in student character with the help of teachers. Thus the character change that occurs is a change that occurs because of the school environment and the help of teachers or the way teachers teach.

Teaching techniques vary widely depending on the situation and conditions experienced. [6] Teaching quality is the most dominant factor affecting learning outcomes in schools [7]. Teachers are also known as student facilitators in learning so that the teacher's role is very big in learning.

The learning techniques carried out by the teacher certainly play a very important role in the learning process, [8] the importance of professional teachers to prepare materials and media to be used in learning so that learning can be achieved according to objectives. One of the media or techniques the teacher will use in learning is a variation of learning that is rarely used so that it can attract students' attention.

Techniques or activities that can make students happier and enjoy or get closer to the teacher is by holding morning greetings. [4] One of the activities that can be done to provide good examples and habits is the morning greetings. Morning greetings or greetings that are often done by teachers before learning begins, besides that greetings are also called mandatory activities for teachers to start learning.

The problem that is often found related to greeting activities is that many students do not care or are indifferent to the teacher so that the attachment and character of affection are lacking. Besides, greeting activities are often considered trivial or ordinary to do so that greeting activities are limited to the usual greeting. [5] However, if this greeting is varied, it will be able to attract students' attention and can improve the character of student caring.

This research is a research on the development of variations in greetings before and after learning which aims to be able to the moral character of students. So that the problems obtained in the field can be resolved or resolved by the media variation of greetings made.

\section{MATERIAL AND METHODS}

\section{Methods}

This study uses a research and development model to produce a product and will be used in classroom learning. The development model used is the Thiagarajan Four-D development model [9] which consists of four stages of research, namely (1) define, including initial analysis, student analysis, concept analysis, and formulation of learning objectives; (2) planning (design) media selection, format selection, and preparation of various greeting media before and after learning; (3) development, including expert validation and trials; and (4) disseminate, including reproduction, socialization, and reflection.

\section{Instrument}


The data collection instruments used in this study were observation sheets, questionnaires, student assessments, interview sheets, and validation sheets [10]. While the data collection steps used were (1) interviewing the moral character of students; (2) mapping of the framework; (3) writing a draft by the developments made; (4) editor of various greeting media drafts; (5) submission of the draft to the validator; (6) the results of the validator's assessment were revised and then tested on a limited basis; (7) revised trial results; (8) after being revised it was tested extensively; (9) revised trial results; and (10) the product is ready for use and socialization.

\section{Procedures}

In a preliminary study, the development method uses preliminary data on students' moral character. After knowing the moral character of students, it is formulated how the various greeting media are developed. The purpose of this research is to explain the development [11] variations of greetings before and after learning the character of elementary school students. The problem that is often found related to greeting activities is that many students do not care or are indifferent to the teacher so that the attachment and character of affection are lacking. Also, greeting activities are often considered trivial or ordinary to do so that greeting activities are limited to the usual greeting. So it can be concluded that the existing moral character still requires additional learning activities that can foster the education of students' moral character, and through greeting activities before learning and after learning the moral character of students is taught.

\section{Data Analysis}

Apart from the results described above regarding development steps, the validity of the quality of media development resulted from the validator's assessments. Assessment based on the feasibility of the media, the feasibility of language, the feasibility of content/material, and the feasibility of the graphic design.

Table 1 Classification of the Validation Results Assessment

\begin{tabular}{lll}
\hline & Table 1 Classification of the Validation Results Assessment \\
\hline Score Interval & Category & Information \\
\hline $86 \%-100 \%$ & Very Valid & Very good product and ready to use \\
\hline $71 \%-85 \%$ & Valid & Products may be used with revision \\
\hline $56 \%-70 \%$ & Enough Valid & $\begin{array}{l}\text { Products may be used after major revisions by revising } \\
\text { the weaknesses section }\end{array}$ \\
\hline $41 \%-55 \%$ & Less Valid & The failed product must not be used \\
\hline $25 \%-40 \%$ & Tidak Valid & The failed product must not be used \\
\hline Adapted from [12] & &
\end{tabular}

The table above explains how the validity of the various salam development media so that the quality and measuring power can be used as a benchmark for the feasibility of the media being made. Thus the results of the assessment use validation from media experts, professors, from content/material experts, and design and graphic experts. 


\section{RESULTS AND DISCUSSION}

\section{Developing and Validating \\ The Process of Developing a Variety of Greetings Before and After Learning}

This approach to qualitative research uses problems that have been obtained and then identified and become the focus of research. Logical analysis is still used, especially in the final period of the research process [13]. This study produces a variety of media greetings before and after learning. The implementation of media development under study uses the Thiagarajan four-D model which consists of 4 stages. Among them are the definition stage, planning stage, development stage, and dissemination stage. In detail, it will be described as follows:

\section{Defining Stage}

This defining stage is a stage that is carried out to determine the actual situation before the implementation of various greeting media before and after learning [14], Initial definitions or analyzes obtained from the research sites at SD Negeri 5 Mendo Barat include: 1) the absence of a variety of greetings before and after learning; 2) lack of student moral character; and 3) teachers do not have information or references related to variations in greetings before and after learning.

Student analysis of moral character. The moral character of students possessed is very diverse because of different abilities, backgrounds, and knowledge [15]. Analyzed moral character values [16] including the character of honesty, piety, courtesy, and courtesy, and manners. Based on the data that has been obtained, the moral character of honesty which consists of students always says honestly to teachers and friends, cares about friends, and is not indifferent when invited to discuss results in $30 \%$ of 20 students, the character of piety includes a sense of responsibility and good student cooperation. 30\%, polite and respectful characters with students greeting by shaking hands every time they go to school, speaking politely to teachers and friends as much as $20 \%$, character of manners in the form of helping friends if asked for help as much as $30 \%$.

In the analysis that has been done, the researcher identifies what needs to be followed up with related to moral character. What media is suitable for the student's condition and what conditions are in the classroom. Thus the analysis of the concept, the researcher began compiling the variety of greetings before and after learning the moral character of students.

\section{Design Stage}

Researchers began to design a variety of greeting media with a combination of images and colors so that the resulting media was attractive and easy to understand. This is meant because the media developed is the media used by teachers and students in elementary schools and is used every day [17]. The draft I of various media greetings before and after learning in the form of a book containing a front cover, a foreword, a table of contents, contents, author's biography, and a back cover, on A4 paper size and 12 pt Garamond font.

\section{Development Stage}

The development stage is carried out, namely revising draft I of the media that has been validated by media experts, linguists, content/material experts, and design and graphic experts [18]. Based on the results of the validation of the media experts, it was produced 
$91.5 \%, 90 \%$ of the proficient experts were produced, of the content/material experts it was $92.5 \%$, and from the design and graphic experts, it was produced $88.5 \%$. The revised result of the draft I is then referred to as draft II. The second draft was then tested on a limited basis. Trials were carried out in a limited manner with 5-9 students with random skills, namely high, medium, and high. The results of the limited trial were then made improvements based on suggestions from validators and peers so that it became draft III which was subsequently tested extensively in class IV SD Negeri 5 Mendo Barat.

The final stage in developing various greeting media before and after learning with the Four-D model is the dissemination stage. The distribution of various media of greetings before and after learning is carried out during the KKG (Teacher Working Group) activities in the West Mendo District. The media developed was given as a whole. Each school received 1 variety of greeting media. Before being given, the researcher explained the use of media to the teachers and principals who were present.

\section{Quality Variations of Media Greetings}

The quality of various media for greetings before and after learning is based on validity, effectiveness, and practicality. Validity is based on the results of the media's assessment by the validator. Effectiveness is based on the results of teacher responses and student responses and the results of students' moral character questionnaires. And the practicality section is based on student and teacher activities, descriptions of student activities in the use of various greeting media before and after learning.

The results of the validation of the media experts were $92.5 \%$, the language feasibility was $94 \%$, the content/material feasibility aspect was $88.57 \%$, and from the graphic design feasibility aspect, it was $93.33 \%$. From the results of the feasibility of the variety of greetings by the validator, the average obtained is $92 \%$, thus the product of this development result is very good and can be used as a medium for variations in greetings before and after learning.

The effectiveness of various media for greetings before and after learning resulted from student activities and teacher activities. From the results of the effectiveness of the student's moral character, the score was 96 with a percentage of $91.14 \%$. It can be seen that the greeting activities carried out before and after learning towards students' moral character went well and the tone of improvement. Based on the data that has been obtained, the moral character of honesty which consists of students always tells the truth to teachers and friends, cares about friends, and is not indifferent when invited to discuss resulted in $60 \%$ of 20 students, the character of piety includes a sense of responsibility and good student cooperation. $60 \%$, polite and respectful characters with students greeting by shaking hands every time they go to school, speaking politely to teachers and friends as much as $70 \%$, character of manners in the form of like helping friends when asked for help as much as $70 \%$. So that there is an increase in the data obtained at the initial stage of observation with the effectiveness of the variety of greetings before learning and after learning on the moral character of students.

The effectiveness data of the variety of greetings before and after learning resulted from the teacher's response to $93.33 \%$ of the process. It can be seen from the greeting activities before and after learning the moral character of students. The moral character of honesty which consists of students always tells the truth to teachers and friends, cares about friends, and is not indifferent when invited to discuss, the character of piety includes a sense of responsibility and good student cooperation, polite and respectful character with students 
greeting by shaking hands every time you go to school, talk politely to teachers and friends, the character of manners in the form of like helping friends when asked for help. But what is more important is that the teacher's relationship with students becomes closer and there is a moral character [16].

Concerning the level of practicality in development research, that practicality refers to the user level to provide an agreement that the media can be used and liked in learning activities [19]. Thus the media for variations in greetings before and after learning can be called practical media because the level of use and level of liking have high values.

Media variations in greetings before and after learning have an important position, this is because the media is one part of the source of greeting activities every day before and after learning [20]. The appropriate variety of greetings media will support the realization of the expected goals. Therefore, the formation of students' moral character can be realized by using various media in greeting before and after learning.

\section{DISCUSSION}

The moral character found in students in elementary schools is very diverse, [21] Student character values depend on the development of students according to the environment and parenting styles. With the variation of greetings aimed at developing students 'moral character, it will be able to help students' poor moral character based on data obtained from preliminary observations. The development of various greetings developed in the form of activities that require direct communication between teachers and students, [22] Communication is carried out using variations of greetings that foster closeness and increase student morale such as variations in shaking hands, variations in clapping, variations in dancing, and so on. Good communication will foster good results for teachers and students, especially on moral character.

\section{CONCLUSION}

The conclusion from this development is that at the initial stage of the definition, 1) there is no media variation in greetings before and after learning; 2) lack of student moral character; and 3) teachers do not have information or references related to variations in greetings before and after learning. Researchers began to design a variety of greetings media with preface, table of contents, contents, author's biography, and back cover, with A4 paper size and 12 pt Garamond font. The variety of media greetings before and after learning resulted from the teacher's response to $93.33 \%$ of the process. It can be seen from the greeting activities before and after learning the moral character of students. The moral character is not indifferent when invited to discuss, resulting in $60 \%$ of the 20 students, the character of piety including a sense of responsibility and good cooperation of students as much as $60 \%$, the character of polite and respectful with students greeting by shaking hands every time they go to school, speaking politely $70 \%$ of teachers and friends, the character of manners in the form of helping friends if asked for help is $70 \%$.

\section{REFERENCES}

[1] Mafidin, "Literature Study On The Role Of Muhammadiyah In Developing Islamic Education In Indonesia" J. Tarbawi, vol. 1, no. 1, pp. 43-53, 2012,

Page 94 of 96 
[2] D. Setiawan, "The Impact of Information and Communication Technology Development on Culture," J. SIMBOLIKA Res. Learn. Commun. Study, vol. 4, no. 1, p. 62, 2018, doi: 10.31289/simbollika.v4i1.1474.

[3] U. Latifa, "Developmental Aspects of Elementary School Children: Problems and Their Development," J. Multidiscip. Stud., vol. 1, no. 2, pp. 185-196, 2017.

[4] A. Nugroho and A. N. Pangestika, "Implementation of Morning Greetings in the Context of Cultivating the Communicative Character of Elementary School Students," ELSE (Elementary Sch. Educ. Journal), vol. 1, pp. 2-6, 2017.

[5] L. Il Makhasunah, "Analysis of Teacher Skills in Conducting Variations in Class V Learning Disd Budi Utomokus Group, Mijen District, Semarang City," Lib.Unnes.Ac.Id, pp. 1-192, 2016, https://lib.unnes.ac.id/24451/1/1401412368.

[6] Rosidah;., "Application Of Problem Based Learning ( $\mathrm{Pbl}$ ) Model In Learning Basic Chemical Laws Assessed From The Activities And Learning Results Of Class X Ipa Students Of Sma Negeri 2 Surakarta In 2013/2014 Academic Year," J. Chem. Inf. Model., vol. 53, no. 9, pp. 8-24, 2018, doi: 10.1017/CBO9781107415324.004.

[7] Maralih, "The Role of Supervision in Improving the Quality of Education," J. Qathruna, 2014, vol 1, no. 1, p. 179.

[8] M. Nurtanto, "Developing Teacher Professional Competence in Preparing Quality Learning, "Pros. Semin. Nas. Inov. Educator. Inov. Based Learning. Character in Facing Masy. Econ. ASEAN, 2014.

[9] D. Kurniawan et al., "Development Of Learning Devices Using The 4-D Thiagarajan Course Media Screencast-O-Matic Course," J. Siliwangi, 2017. vol 3, no. 1, p. 214.

[10] H. Hasanah, "OBSERVATION TECHNIQUES (An Alternative to Qualitative Data Collection Method in Social Sciences)," At-Taqaddum, vol. 8, no. 1, p. 21, 2017, doi: 10.21580/at.v8i1.1163.

[11] W. Warsilah and W. Wijayanti, "The Role of the Principal in the Development of School Culture at Upt Sd, Moyudan District, Sleman Regency," J. Akuntabilitas Manaj. Pendidik., vol. 3, no. 1, pp. 97-113, 2015, doi: 10.21831/amp.v3i1.6273.

[12] A. Murtadho, S. Wulandari, M. Wahid, and E. Rustiadi, "Regional Development and Changes in Land Cover in Purwakarta Regency as the Impact of the Jakarta-Bandung Conurbation Process," J. Reg. Rural Dev. Plan., 2018, doi: 10.29244/jp2wd.2018.2.2.195208. vol 2, no. 2, p. 195-208

[13] S. Sunarto, P. Purwanto, and S. P. Hadi, "Quantification of greenhouse gas emissions from municipal solid waste recycling and disposal in Malang city Indonesia," J. Ecol. Eng., 2017, doi: 10.12911/22998993/70237. vol 18, no. 3, p. 74-82.

[14] A. A. Nugroho and H. Purwati, "Implementation of Morning Greetings in the Context of Cultivating the Communicative Character of Elementary School Students," Euclid, 2015, doi: 10.33603/e.v2i1.355. vol 1, no. 2, p. 2-6.

[15] M. I. Arrosyad, S. N. Oktaviani, H. Eftia, N. Karisma, and B. Meliyana, "School Cultural Values in Fostering Student Religious Activities," Atthulab Islam. Relig. Teach. Learn. J., vol. 5, no. 1, pp. 129-139, 2020, doi: 10.15575/ath.v5i1.7697.

[16] A. Yusuf, "Understanding character education," J. Chem. Inf. Model., vol. 53, no. 9, pp. 1689-1699, 2015, doi: 10.1017/CBO9781107415324.004.

[17] M. I. Arrosyad, A. Suryadin, and H. J. Prayitno, "Flip Fabric and Name Board (Case Study in Pangkalpinang City, Bangka Belitung Islands)," Din. J. Ilm. Pendidik. Dasar, vol. 12, no. 1, p. 44, 2020, doi: 10.30595/dinamika.v12i1.6551. 
[18] R. O. Hananta and T. Sukardi, “Development of Video Media Model in Learning Practice of Lathe Machining," J. Din. Vokasional Tek. Mesin, 2018, doi: 10.21831/dinamika.v3i2.21409. vol 3, no. 2, p. 121-129.

[19] B. Purwanti, "Development of Mathematics Learning Video Media with Assure Model" J. Kebijak. dan Pengemb. Pendidik., 2015. vol 3, no. 1, p. 42-47.

[20] M. I. Arrosyad, L. F. Ulfa, M. Mersy, C. Claudia, and I. E. Safitri, "The Role of School Principals in Developing School Culture at SD Negeri 5 Mendo Barat," Sustain. J. Kaji. Mutu Pendidik., vol. 3, no. 1, pp. 1-7, 2020, doi: 10.32923/kjmp.v3i1.1149.

[21] L. Yuliana, "Cultivating Moral Values in Early Childhood," J. Ilm. WUNY, 2015, doi: 10.21831/jwuny.v15i1.3527. vol 3, no. 2, p. 91

[22] E. N. Inah, "The Role Of Communication In Teacher And Student Interaction," AlTa'dib, 2015. vol 8, no. 2, p. 150.

\section{http://jurnalnasional.ump/index.php/dinamika}

